\title{
Matrix metalloproteinases 2 and 9 in rabbits with doxorubicin-induced cardiomyopathy ${ }^{1}$
}

\author{
Sheila S.S. Nogueira², Marlos G. Sousa ${ }^{3 *}$, Fabio N. Gava ${ }^{2}$, \\ Fernando A. Rosa ${ }^{2}$, Guilherme D. Melo ${ }^{4}$, Gustavo Dittrich ${ }^{3}$, \\ Gisele F. Machado ${ }^{4}$ and Aparecido A. Camacho ${ }^{2}$
}

\begin{abstract}
Nogueira S.S., Sousa M.G., Gava F.N., Rosa F.A., Melo G.D., Dittrich G., Machado G.F. \& Camacho A.A. 2018. Matrix metalloproteinases 2 and 9 in rabbits with doxorubicin-induced cardiomyopathy. Pesquisa Veterinária Brasileira 38(2):320-327. Departamento de Medicina Veterinária, Universidade Federal do Paraná, Rua dos Funcionários 1540, Cabral, Curitiba, PR 80035-050, Brazil. E-mail: marlos98@ufpr.br

Some studies have shown the role played by matrix metalloproteinases and their inhibitors in doxorubicin cardiotoxicity. In this study, we sought to investigate how plasma and myocardial MMP 2 and 9 perform in rabbits with doxorubicin-induced cardiomyopathy, searching for a correlation between the activity of these collagenases and cardiac remodeling. Cardiomyopathy was induced by doxorubicin given intravenously twice a week for six consecutive weeks. Plasma MMP activity and the echocardiogram were assessed at baseline, and at 15 and 45 days after first injection of doxorubicin. The myocardial activity of these enzymes was solely evaluated in nine rabbits at 45 days, and results were compared with nine healthy controls. We only identified the full-length forms of both MMP 2 and 9 throughout the study. The plasma pro-MMP 2 reduced along the deterioration of cardiac function, while the pro-MMP 9 increased significantly at T45 as compared to baseline and T15. A negative significant correlation was found to exist between the plasma activity of pro-MMP 2 and mitral E-to-mitral septal annular early diastolic velocity ratio, which is an estimate of mean left atrial pressure and congestion. Only pro-MMP 2 was found in myocardial samples, and mean activity of such enzyme was statistically lower than that recorded for healthy controls. Although no active form was documented for either collagenase, the duration of the treatment with doxorubicin played a role in the alteration of plasma pro-forms activity. However, these changes could not be associated with most echocardiographic parameters that are supportive of cardiac remodeling.

INDEX TERMS: Matrix metalloproteinases, rabbits, doxorubicin, cardiomyopathy, zymography, enzyme activity, cardiac disease, echocardiogram, collagenase, clinics.
\end{abstract}

RESUMO.- [Metaloproteinases de matriz 2 e 9 em coelhos com cardiomiopatia induzida pela doxorrubicina.] Alguns estudos já demonstraram o papel exercido pelas metaloproteinases

\footnotetext{
${ }^{1}$ Received on August 30, 2016.

Accepted for publication on November 18, 2016.

${ }^{2}$ Departamento de Clínica e Cirurgia Veterinária, Universidade Estadual Paulista (Unesp), Via de Acesso Prof. Paulo Donato Castellane s/n, Jaboticabal, SP, 14870-000, Brasil.

${ }^{3}$ Departamento de Medicina Veterinária, Universidade Federal do Paraná (UFPR), Rua dos Funcionários 1540, Cabral, Curitiba, PR, 80035-050, Brasil. *Corresponding author: marlos98@ufpr.br

${ }^{4}$ Departamento de Clínica, Cirurgia e Reprodução Animal, Unesp, Rua Clóvis Pestana 793, Ipanema, Araçatuba, SP 16050-680, Brasil.
}

de matriz e seus inibidores na cardiotoxicidade promovida pela doxorrubicina. Assim, este estudo teve como objetivo investigar o comportamento das MMPs 2 e 9 plasmáticas e miocárdicas em coelhos com cardiomiopatia induzida pela doxorrubicina, buscando determinar se há correlação entre a atividade dessas colagenases e o remodelamento cardíaco. A cardiomiopatia foi induzida pela doxorrubicina aplicada por via intravenosa duas vezes por semana ao longo de seis semanas consecutivas. A atividade plasmática das MMPs e o ecocardiograma foram avaliados no momento basal e aos 15 e 45 dias após a primeira aplicação da doxorrubicina. A atividade miocárdica dessas enzimas foi quantificada em apenas nove coelhos aos 45 dias e os resultados comparados 
com outros nove controles saudáveis. Foram identificadas apenas as formas inativas das MMPs 2 e 9 durante todo o estudo. A pro-MMP 2 plasmática reduziu à medida que a função cardiaca se deteriorou, enquanto a pro-MMP 9 aumentou significativamente em T45 quando comparada aos momentos basal e T15. Houve correlação negativa significativa entre a atividade plasmática da pro-MMP 2 e a relação entre E mitral e a velocidade anular mitral no início da diástole, um parâmetro que permite estimar a pressão atrial esquerda média e a congestão. Apenas a pro-MMP 2 foi documentada nas amostras miocárdicas dos coelhos com cardiomiopatia e atividade media dessa enzima foi estatisticamente menor que aquela observada nos controles saudáveis. Embora a forma ativa de ambas as colagenases não tenha sido identificada, o tempo de tratamento com doxorrubicina interferiu na atividade das formas inativas plasmáticas. Contudo, essas alterações não se associaram com a maioria dos parâmetros ecocardiográficos que indicam remodelamento cardíaco.

TERMOS DE INDEXAÇ̃̃O: Metaloproteinases, coelhos, doxorrubicina, cardiomiopatia, zimografia, atividade enzimática, cardiopatia, ecocardiograma, colagenase, clínica.

\section{INTRODUCTION}

Doxorubicin is an anthracycline drug used to treat several malignant neoplasms in people and animals, such as solid tumors, leukemia, and lymphoma. However, the development of a dose-dependent toxicity, which results in hematological, cutaneous, renal, gastrointestinal, and especially cardiac impairment, may preclude its widespread use. Several cellular mechanisms are implicated in this cardiotoxicity, including necrosis and apoptosis. It is believed that the accumulation of doxorubicin within the mitochondria results in the production of free radicals and peroxidation reactions (Speyer et al. 1988, Steinherz et al. 1991, Shakir \& Rasul 2009).

Besides its effects on the cardiomyocytes, the prolonged use of doxorubicin is also known to alter collagen, a protein that is the fundamental extracellular matrix (ECM) scaffold supporting cell proliferation, differentiation, and regeneration (Goto et al. 2003, Diez 2010). The amount and type of collagen present in the ECM is determined by the complex equilibrium between its synthesis and degradation, with the latter being regulated by the opposing role of matrix metalloproteinases (MMPs), a family of zinc-dependent proteinases that is characterized by their ability to degrade the ECM components, as well as the tissue inhibitors of metalloproteinase (TIMPs), an enzymatic family capable of inhibiting the activity of MMP (Navarro et al. 2006).

In people, the blood levels of MMP have been shown to be altered in several pathologic conditions, including cancer, kidney diseases, rheumatoid arthritis, and systemic sclerosis, although some circumstances, such as acute viral hepatitis, have resulted in reduced circulating MMP levels (Nikkola et al. 2005). Evidences from prior studies suggest that both MMP 2 and MMP 9 play an active role in the remodeling process attributable to several cardiovascular diseases (Kizaki et al. 2006). People with dilated cardiomyopathy were found to have increased levels of these two MMP (Li et al. 1998, Thomas et al. 1998, Spinale et al. 2000), as well as rats with experimentally-induced hypertensive diseases (Robert et al. 1997) and acute myocardial infarction (Peterson et al. 2000).
The concentration of these substances also increased when rats were given anthracyclines either for a short (Kizaki et al. 2006) or long (Adamcova et al. 2010) period of time. In dogs, a study documented increased levels of MMP 9 when atrial fibrillation was present as compared to animals with no arrhythmia (Zhang et al. 2008). Conversely, another study that included dogs with naturally-occurring mitral valve disease found a reduction in plasma MMP 9 activity as the left-ventricular diameter at end-systole increased (Ljungvall et al. 2011).

Because of the renowned cardiotoxicity of doxorubicin, the authors hypothesized that MMP 2 and 9 would be progressively altered in rabbits undergoing anthracycline therapy, and the fluctuation in their circulating levels could be used as a surrogate for myocardial remodeling. Therefore, the goal of this investigation was to evaluate how MMP 2 and 9 perform in rabbits with doxorubicin-induced cardiomyopathy, searching for a correlation between these substances and the cardiac morphofunctional alterations frequently observed in this well-recognized experimental model.

\section{MATERIALS AND METHODS}

Animals. Twelve purpose-bred mature male New Zealand White rabbits $(3.0 \pm 1.0 \mathrm{~kg})$ were recruited from the institutional husbandry and breeding facility for a prospective longitudinal experimental study. A complete physical examination, CBC, and serum biochemical analysis were performed to rule out any condition that could preclude the inclusion of the animals into the study. The rabbits were maintained in individual cages and were fed commercially available rabbit food and given water ad libitum throughout the study duration. To induce the toxic cardiomyopathy, we followed a protocol previously investigated and reported by our laboratory team (Gava et al. 2013). Briefly, the ear was clipped and the skin was thoroughly disinfected, followed by the introduction of a winged catheter into the auricular vein. The diluted doxorubicin $(2 \mathrm{mg} / \mathrm{mL})$ was given over approximately five minutes intravenously at $1 \mathrm{mg} / \mathrm{kg}$ twice a week (Mondays and Thursdays) for six consecutive weeks. Forty-five days after doxorubicin was first given, the animals were euthanized with an intravenous propofol injection followed by potassium chloride. Also, we obtained heart samples from another nine healthy mature rabbits $(2.8 \pm 0.8 \mathrm{~kg})$ to use as controls for myocardial MMP activity.

The study was entirely conducted in accordance with the guidelines outlined in the National Institutes of Health Guide for the Care and Use of Laboratory Animals and was approved by the institutional animal experimentation ethical committee under protocol 2243/13.

Determination of enzyme activity. The plasma activity of MMP 2 and 9 was determined in samples collected in tubes containing citrate at baseline (T0), and at 15 (T15) and 45 (T45) days after the first injection of doxorubicin was given. The myocardial activity of these enzymes was determined at $\mathrm{T} 45$.

After centrifugation of blood samples, the plasma was transferred to sterile tubes, which were stored at $-80^{\circ} \mathrm{C}$ until the samples were analyzed. Also, cardiac tissue samples were kept frozen at $-80^{\circ} \mathrm{C}$ until the myocardial activity of MMP was to be determined. Immediately before, they were thaw and deposited in an ice-containing recipient to maintain temperature 
at $4^{\circ} \mathrm{C}$. The tissue was macerated in $1.0 \mathrm{~mL}$ of extraction buffer (50mM Tris-HCl, 150mM NaCl, 5mM CaCl2, 0.05\% Brij-35), plus a protease inhibitor cocktail (Complete, EDTA-free 11873 580 001, Roche), transferred to a microcentrifuge tube, and centrifuged at $12,000 \times \mathrm{g}$ for 15 minutes at $4^{\circ} \mathrm{C}$. Both plasma and myocardial total proteins were quantified using the bicinchoninic acid assay (BCA 23225, Pierce Biotechnology) following the manufacturer's instructions.

Zymography was performed in accordance with the technique formerly published for tissue (Machado et al. 2010) and plasma (Melo et al. 2011) samples. In brief, we used zymogram polyacrylamide gels containing $1 \mathrm{mg} / \mathrm{mL}$ of gelatin, with $15 \mu \mathrm{g}$ of protein from each sample undergoing electrophoresis for 90 minutes at $125 \mathrm{~V}$, using Tris-Glicine $\mathrm{pH} 8.3$ as non-denaturing running buffer, at $4^{\circ} \mathrm{C}$. Upon completion, the gels were rinsed in Triton X-100 2.5\% for 30 minutes at room temperature, followed by incubation in enzymatic activation buffer (50mM Tris, $200 \mathrm{mM} \mathrm{NaCl}, 5 \mathrm{mM} \mathrm{CaCl2,} \mathrm{0.2 \%} \mathrm{Brij} \mathrm{35,} \mathrm{pH} \mathrm{7.5)}$ for 20 hours at $37^{\circ} \mathrm{C}$ under gentle shaking. Finally, we stained the gels with $0.5 \%$ of Coomassie brilliant blue R-250 diluted in $45 \%$ methanol, 10\% acetic acid, and 45\% distilled water for 30 minutes, and then destained with $45 \%$ methanol and $10 \%$ glacial acetic acid for 30 minutes.

When the procedure was completed, the gels were digitalized (ImageQuant LAS 4000, GE) and densitometry was used to assess the gelatinolytic activity of MMPs using the open-source software ImageJ 1.46r (Wayne Rasband, National Institutes of Health, USA; http://rsb.info.nih.gov/ij). Identification of MMP was based on their molecular weights (Fig.1) which were previously standardized in canine mammary gland adenocarcinoma using human recombinant MMP 2 and 9 (pro-MMP 9: 92 kDa; active MMP 9: 86 kDa; pro-MMP 2: $72 \mathrm{kDa}$; active MMP 2: $66 \mathrm{kDa}$ ) (Machado et al. 2010). The results were expressed in arbitrary units, which represent the integrated density of the clear gelatinolytic bands against the dark blue background.

Echocardiography. Every animal enrolled in the study underwent an echocardiographic examination in accordance with the technique described elsewhere (Stypmann et al. 2007). This procedure was undertaken at baseline, at T15, and at T45 utilizing a 7.5-10.0 MHz phased array transducer. Neither sedation nor anesthesia was used during the echocardiographic assessment, and only physical restraint was necessary.

With the rabbit positioned in right lateral recumbency, transverse views of the heart were used to measure the left-ventricular end-systolic diameter $\left(\mathrm{LV}_{\mathrm{s}}\right)$, left-ventricular end-diastolic diameter $\left(\mathrm{LV}_{\mathrm{d}}\right)$, interventricular septal thickness

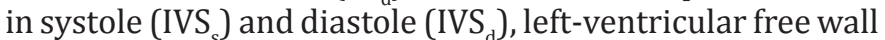
in systole $\left(\mathrm{FW}_{\mathrm{s}}\right)$ and diastole $\left(\mathrm{FW}_{\mathrm{d}}\right)$, E-point septal separation (EPSS), and the left atrium (LA) and aortic (AO) diameters. Upon changing the recumbency to left lateral, apical images of the heart were recorded, which allowed the determination of mitral $\mathrm{E}\left(\mathrm{E}_{\mathrm{m}}\right)$ and $\mathrm{A}\left(\mathrm{A}_{\mathrm{m}}\right)$ waves, and the isovolumic relaxation time (IVRT). Diastolic and systolic mitral annular velocities were also documented at the septal $\left(\mathrm{E}_{\text {sep }}, \mathrm{A}_{\text {sep }}, \mathrm{S}_{\text {sep }}\right)$ and lateral $\left(E_{\text {lat }}, A_{\text {lat }}, S_{\text {lat }}\right)$ sites. Some of these parameters were used for calculation of several echocardiographic indices.

Statistical analyses. The results of plasma MMP activity underwent the D'Agostino-Pearson omnibus normality test and did not attain a normal distribution. Therefore, we used the

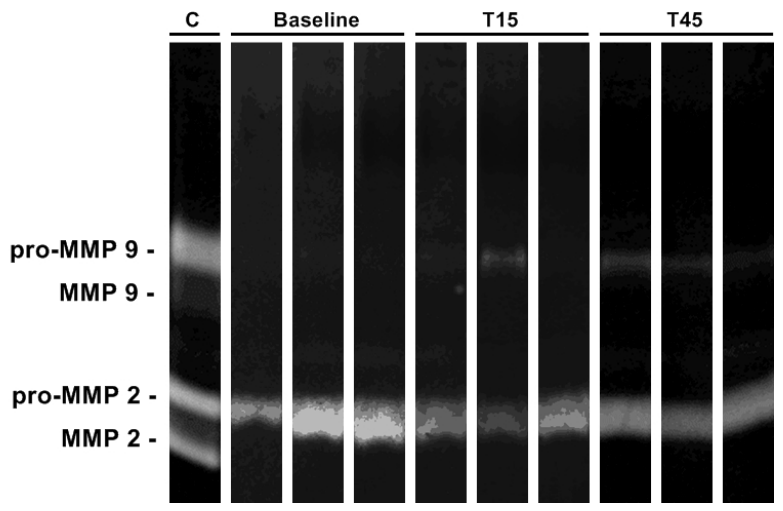

Fig.1. Representative plasma zymograms illustrating the gelatinolytic bands corresponding to pro-MMP 9 (92 kDa), active MMP 9 (86 kDa), pro-MMP 2 (72 kDa), and active MMP 2 (66 kDa). Figure was adjusted to improve contrast. C: canine mammary adenocarcinoma used as positive control for molecular weights; Baseline, T15 and T45: plasma samples of three purpose-bred New Zealand white rabbits (same animals) treated with intravenous doxorubicin twice a week.

Friedman test followed by Dunn's test to compare MMP plasma activity at T0, T15 and T45. Because the myocardial enzyme activity was normally distributed, an unpaired T test was used to compare normal and diseased rabbits. Finally, Spearman's test and logistic regression were utilized to look for correlation between either plasma or myocardial MMP activity and the echocardiographic parameters that indicated remodeling and deterioration of cardiac function. All analyses were performed using the software Prism v. 5.0 (Graphpad, San Diego, CA), with significance set at $P<0.05$.

\section{RESULTS}

The active forms of MMP 2 and 9 were not documented in any rabbit. On the contrary, the full-length form of MMP 2 (pro-MMP 2) was found in all baseline, T15, and T45 samples. Also, pro-MMP 9 could not be identified in any baseline sample, yet it was present in $8.3 \%$ and $91.7 \%$ of $\mathrm{T} 15$ and T45 samples respectively.

When the gelatinolytic activity (expressed with arbitrary units) of pro-MMP 2 at baseline, T15 and T45 were compared, a significant reduction was observed from baseline to T45 $(P<0.05)$. For pro-MMP 9, a significant increase was documented from baseline to T45 $(P<0.05)$, as well as from T15 to T45 $(P<0.05)$ (Fig. 2). A negative correlation was found to exist between the two pro-MMP $\left(\mathrm{R}^{2}=0.1865\right.$; best-fit line: pro-MMP $\left.9=10^{(-0.8962 \cdot \text { pro-MMP } 2-0.5074)}\right)$.

The significant increase in $\operatorname{LV}_{\mathrm{s}}(P=0.0101)$ together with the reduction in FS $(P<0.0001)$ and EF $(P<0.0001)$ documented over 45 days point to the impairment in systolic function. Also, the significant reduction in IVRT $(P=0.0001)$, $\mathrm{E}_{\text {sep }} / \mathrm{A}_{\text {sep }}(P<0.0001)$, and $\mathrm{E}_{\text {lat }} / \mathrm{A}_{\text {lat }}(P<0.0001)$ are suggestive of diastolic dysfunction. Finally, the increase in the ratio between $\mathrm{E}_{\mathrm{m}}$ and $\mathrm{E}_{\mathrm{sep}}(P=0.0094)$ may indicate the development of congestion over time. 
Although the echocardiographic parameters showed atrioventricular remodeling, reduction of contractile function, and impairment of diastolic function (Table 1) as the cumulative dose of doxorubicin increased, neither linear nor non-linear correlations were found to exist between the plasma activity of either pro-MMP 2 or pro-MMP 9 and the several parameters obtained at baseline, T15 and T45, except for $\mathrm{E}_{\mathrm{m}}$-to- $\mathrm{E}_{\text {sep }}$ ratio $\left(\mathrm{R}^{2}=0.1521 ; P=0.0301\right)$, an index of congestion, which was inversely correlated with pro-MMP 2 (Fig.3).

Within the myocardium of both healthy and diseased rabbits, only the pro-form of MMP 2 was identified (Fig.4). A lower significant mean $(P=0.0498)$ was demonstrated for the animals with cardiomyopathy in comparison with the subset of healthy animals (Fig.5). However, no correlation existed between the myocardial activity of pro-MMP 2 and the plasma activity of the same enzyme at T45. Likewise, no correlation was seen with the echo parameters of the same animals at $\mathrm{T} 45$.
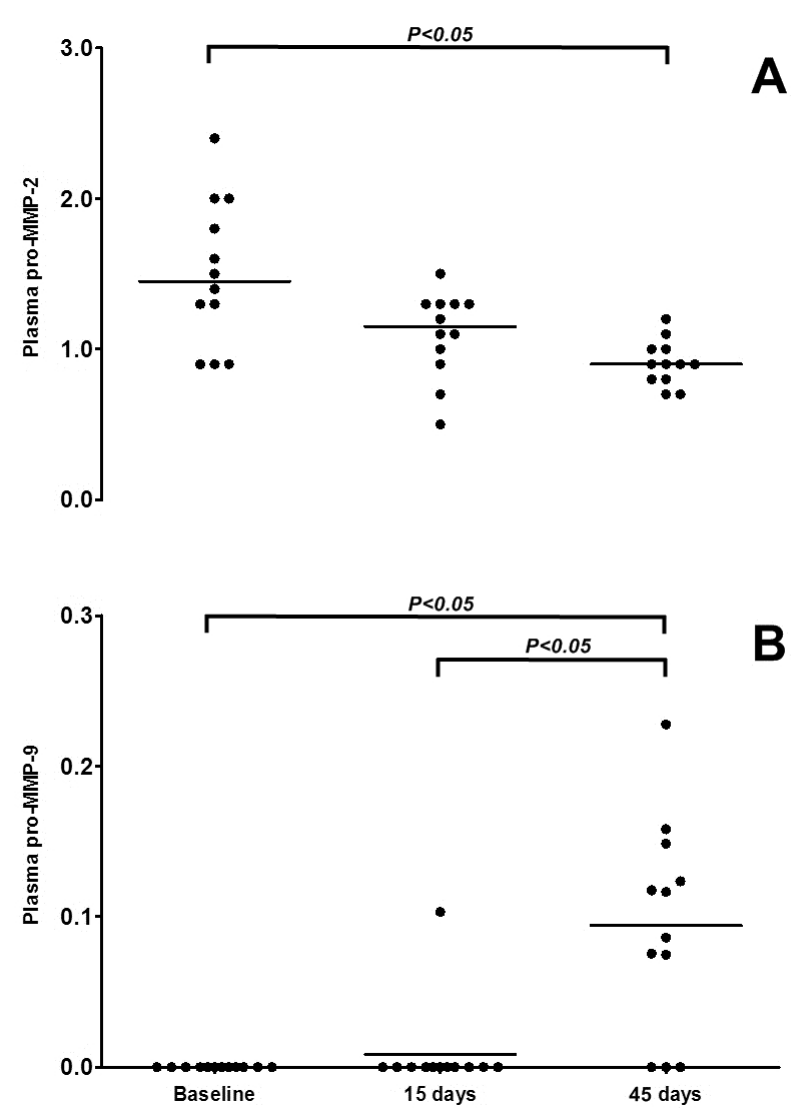

Fig.2. Results of zymographic assay to detect matrix metalloproteinases 2 and 9 activities in plasma samples of New Zealand white rabbits being given doxorubicin twice a week for 6 weeks. Medians are shown (lines), as well as individual values of the inverse optical density units (arbitrary units) of the pro-forms of MMP 2 and 9 obtained from the gelatinolytic bands. (A) A significant reduction $(P=0.0011)$ was documented for pro-MMP 2 (T0 versus T45: $\mathrm{P}<0.05$ ), whereas $(\mathrm{B})$ a significant increase $(P=0.0002)$ was observed for pro-MMP 9 (T0 versus T45: $\mathrm{P}<0.05$; $\mathrm{T} 15$ versus T45: $\mathrm{P}<0.05)$.

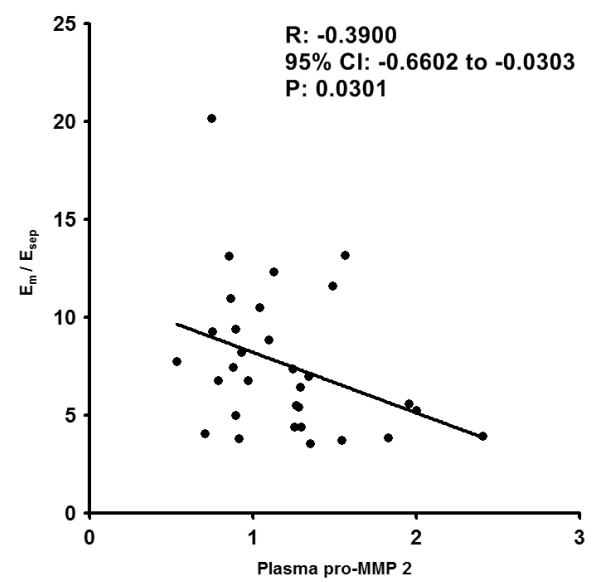

Fig.3. Scatterplot exhibiting a significant correlation between the plasma pro-MMP 2 activity (in arbitrary units) and the ratio between mitral $\mathrm{E}$ wave and mitral annular early diastolic velocity at the septal site in rabbits treated with doxorubicin for 6 weeks. Best-fit line is shown.

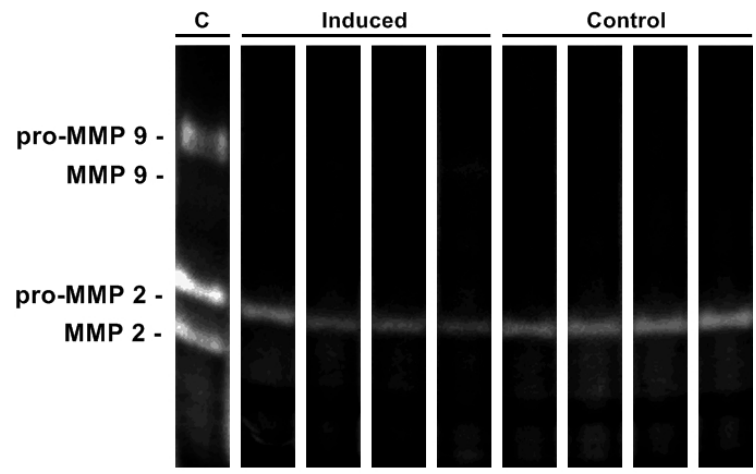

Fig.4. Representative zymograms from eight myocardial samples showing the gelatinolytic bands that correspond to pro-MMP 9 (92 kDa), active MMP 9 (86 kDa), pro-MMP 2 (72 kDa), and active MMP 2 (66 kDa). Figure was adjusted to improve contrast. C: canine mammary adenocarcinoma used as positive control; Control: tissue from four healthy rabbits; Induced: tissue from four rabbits treated with doxorubicin twice a week for 6 weeks.

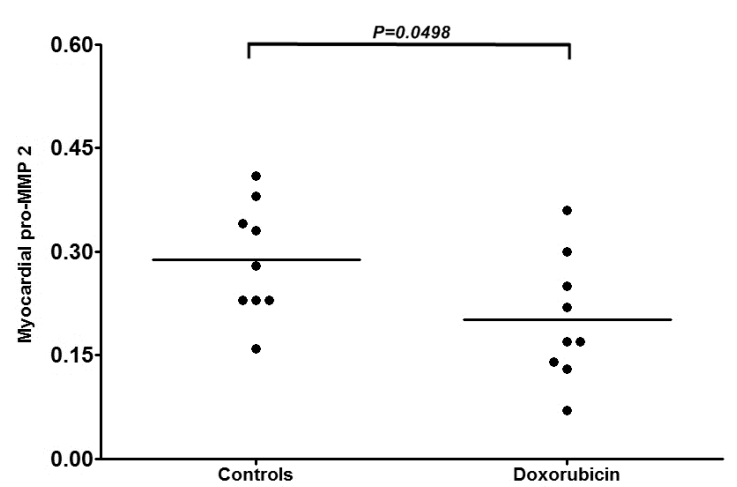

Fig.5. Myocardial full-length MMP 2 activity obtained in healthy rabbits $(n=9)$ and rabbits treated with doxorubicin $(n=9)$ twice a week for 6 weeks. Means, expressed as arbitrary units, were significantly different between both groups $(P=0.0498)$ as assessed by an unpaired $\mathrm{T}$ test. 
Table 1. Echocardiographic data (mean \pm SD) in New Zealand white rabbits being given doxorubicin intravenously twice a week for six consecutive weeks

\begin{tabular}{|c|c|c|c|c|}
\hline & Baseline & 15 days & 45 days & $P($ Friedman $)$ \\
\hline \multicolumn{5}{|c|}{ Measured parameters } \\
\hline $\mathbf{L V}_{\mathrm{s}}(\mathrm{mm})$ & $8.63 \pm 0.98^{\mathrm{a}}$ & $9.17 \pm 1.14^{\mathrm{ab}}$ & $10.26 \pm 1.40^{\mathrm{b}}$ & 0.0101 \\
\hline $\mathbf{L V}_{\mathbf{d}}(\mathrm{mm})$ & $13.67 \pm 1.36$ & $13.62 \pm 1.59$ & $13.05 \pm 1.69$ & 0.5991 \\
\hline IVS $_{\mathbf{s}}(\mathrm{mm})$ & $4.45 \pm 0.49$ & $3.98 \pm 0.47$ & $4.27 \pm 0.73$ & 0.1540 \\
\hline $\mathbf{I V S}_{\mathbf{d}}(\mathrm{mm})$ & $3.35 \pm 0.32$ & $3.00 \pm 0.58$ & $3.17 \pm 0.64$ & 0.2949 \\
\hline $\mathbf{F W}_{\mathbf{s}}(\mathrm{mm})$ & $4.62 \pm 0.38^{\mathrm{a}}$ & $3.37 \pm 0.52^{\mathrm{b}}$ & $3.37 \pm 0.78^{b}$ & $<0.0001$ \\
\hline $\mathbf{F W}_{\mathbf{d}}(\mathrm{mm})$ & $3.51 \pm 0.73^{\mathrm{a}}$ & $2.36 \pm 0.52^{\mathrm{b}}$ & $2.46 \pm 0.50^{\mathrm{ab}}$ & $<0.0001$ \\
\hline EPSS $(\mathrm{mm})$ & $0.95 \pm 0.35$ & $1.03 \pm 0.31$ & $1.25 \pm 0.64$ & 0.4687 \\
\hline IVRT (ms) & $47.67 \pm 11.54^{\mathrm{a}}$ & $29.36 \pm 9.01^{b}$ & $28.85 \pm 8.97^{b}$ & 0.0001 \\
\hline $\mathbf{S}_{\text {sep }}(\mathrm{cm} / \mathrm{s})$ & $10.01 \pm 2.85$ & $9.62 \pm 3.88$ & $9.02 \pm 1.16$ & 0.7164 \\
\hline $\mathbf{S}_{\text {lat }}(\mathrm{cm} / \mathrm{s})$ & $8.55 \pm 1.46$ & $8.36 \pm 2.74$ & $7.78 \pm 1.08$ & 0.7702 \\
\hline \multicolumn{5}{|c|}{ Calculated indices } \\
\hline FS $(\%)$ & $36.77 \pm 3.05^{\mathrm{a}}$ & $32.52 \pm 4.67^{\mathrm{ab}}$ & $21.36 \pm 2.43^{b}$ & $<0.0001$ \\
\hline EF $(\%)$ & $70.64 \pm 4.05^{\mathrm{a}}$ & $64.77 \pm 6.44^{\mathrm{ab}}$ & $47.14 \pm 4.24^{\mathrm{b}}$ & $<0.0001$ \\
\hline LA/Ao & $1.51 \pm 0.15$ & $1.51 \pm 0.21$ & $1.69 \pm 0.23$ & 0.1304 \\
\hline $\mathbf{E}_{\mathrm{m}} / \mathbf{A}_{\mathrm{m}}$ & $1.23 \pm 0.24$ & $1.13 \pm 0.23$ & $1.06 \pm 0.27$ & 0.2835 \\
\hline $\mathrm{E}_{\mathrm{m}} /$ IVRT & $9.94 \pm 4.11$ & $16.90 \pm 4.67$ & $23.98 \pm 21.84$ & 0.0641 \\
\hline$E_{\text {sep }} / A_{\text {sep }}$ & $1.75 \pm 0.51^{\mathrm{a}}$ & $1.22 \pm 0.16^{\mathrm{ab}}$ & $0.75 \pm 0.27^{b}$ & $<0.0001$ \\
\hline $\mathbf{E}_{\mathrm{m}} / \mathbf{E}_{\text {sep }}$ & $5.60 \pm 2.87^{\mathrm{a}}$ & $7.35 \pm 2.60^{\mathrm{ab}}$ & $10.25 \pm 4.17^{b}$ & 0.0094 \\
\hline $\mathbf{E}_{\text {lat }} / \mathbf{A}_{\text {lat }}$ & $1.84 \pm 0.48^{\mathrm{a}}$ & $1.30 \pm 0.15^{\mathrm{ab}}$ & $0.85 \pm 0.34^{b}$ & $<0.0001$ \\
\hline $\mathbf{E}_{\mathrm{m}} / \mathbf{E}_{\text {lat }}$ & $5.20 \pm 2.10$ & $6.66 \pm 1.69$ & $8.18 \pm 5.65$ & 0.1614 \\
\hline
\end{tabular}

Different lowercase letters in the same line indicate significant differences $(P<0.05)$ by Dunn's test. LV left-ventricular end-systolic diameter, $\mathrm{LV}_{\mathrm{d}=}$ left-ventricular end-diastolic diameter, $\mathrm{FS}=$ fractional shortening, $\mathrm{EF}=$ Teichholz-derived ejection fraction, IVS $\mathrm{s}=$ interventricular septal thickness in systole, $\mathrm{IVS}_{\mathrm{d}=}$ interventricular septal thickness in diastole, $\mathrm{FW}_{\mathrm{s}=}$ left-ventricular free wall in systole, $\mathrm{FW}_{\mathrm{d}=}$ left-ventricular free wall in diastole, EPSS = E-point septal separation, LA/Ao = left atrium-to-aorta ratio, $\mathrm{E}_{\mathrm{m}} / \mathrm{A}_{\mathrm{m}=\mathrm{s}}$ mitral E-to-mitral A wave ratio, $\mathrm{IVRT}=$ isovolumic relaxation time, $\mathrm{E}_{\mathrm{m}} / \mathrm{IVRT}=$ ratio between mitral $\mathrm{E}$ wave and isovolumic relaxation time, $\mathrm{E}_{\mathrm{sep}} / \mathrm{A}_{\mathrm{sep}}$ ratio between mitral annular diastolic velocities at the septal site, $\mathrm{S}_{\mathrm{sep}}$ mitral annular systolic velocity at the septal site, $\mathrm{E}_{\mathrm{m}} / \mathrm{E}_{\mathrm{sep}}$ ratio between mitral $\mathrm{E}$ wave and mitral annular early diastolic velocity at the septal site, $\mathrm{E}_{\mathrm{lat}} / \mathrm{A}_{\mathrm{lat}}=\mathrm{ratio}_{\mathrm{set}}$ been mitral annular diastolic velocities at the lateral site, $\mathrm{S}_{\text {lat }=}$ mitral annular systolic velocity at the lateral site, $\mathrm{E}_{\mathrm{m}} / \mathrm{E}_{\text {lat }}$ ratio between mitral $\mathrm{E}$ wave and mitral annular early diastolic velocity at the lateral site.

\section{DISCUSSION}

The induction of a toxic cardiomyopathy occurred over 45 days, with doxorubicin being given twice weekly to the animals. Although the goals of this study were not to demonstrate the compromise of cardiac structure and function, it is clear that doxorubicin, when given in accordance with this protocol, results in remodeling of cardiac chambers and an increasingly impairment of both systolic and diastolic functions, which is supported by our echocardiographic data. Similar findings have been documented in several species, including dogs (Sousa et al. 2014) and rabbits (Gava et al. 2013), in which a significant left ventricular dilation at end-systole have been observed as early as 45 days after doxorubicin started to be injected twice a week.

The matrix metalloproteinases are endopeptidades secreted as full-length proenzymes known as zymogens. These substances are classified as collagenases (MMP 1, 8, 13 and 18), gelatinases (MMP 2 and 9), stromelysins (MMP $3,7,10,11,19$ and 20), matrilysines (MMP 7 and 16), and the membrane-type MMP (MMP 14, 15, 16, 17, 24 and 25) depending on the substrate that they are able to degrade. Their activation occurs at the pericellular environment upon the disruption of cistein- $\mathrm{Zn}^{2+}$ linkages that blocks the reactivity of the active site (Loftus \& Thompson 2002, Visse \& Nagase 2003). In this study, we sought to investigate specifically how the gelatinases perform in rabbits treated with doxorubicin, and whether these substances might be used as surrogates for the severity of myocardial remodeling. Because the pro-MMP 2 is also localized to the sarcomere within the cardiomyocyte, it may be activated without proteolytic processing by the oxidative stress induced by doxorubicin. Since its endogenous inhibitor is also inactivated, MMP 2 proteolyzes specific targets within the cell, which may result in an acute, reversible systolic dysfunction that might increase the cardiotoxicity of doxorubicin (Schulz 2007). Interestingly, in spite of the cardiac dilatation and deterioration of contractile function, plasma MMP 2 and 9 could not be demonstrated in any animal enrolled in this study.

The action of TIMPs may elucidate why only the pro-forms of MMPs could be identified in this investigation (Schulz 2007, Papazafiropoulou \& Tentolouris 2009). Also, Van den Steen and colleagues reported that activated forms of MMP 9 are rarely observed owing to its high instability and fast turnover. When detected, however, the active form is likely indicative of a continuous state of MMP 9 activation (Van den Steen et al. 2006). The pro-forms of both enzymes documented in this study behaved in an inverse fashion, i.e., the plasma activity of 
pro-MMP 2 decreased whereas an increase was observed for pro-MMP 9 as the cardiac compromise worsened. Similarly, a previous study in rats with doxorubicin-induced cardiomyopathy did not document the active forms of both MMP 2 and 9, while pro-MMM 2 was also identified (Ivanová et al. 2012).

Inflammatory mediators activate neutrophils which, in turn, cause the release of MMP 9 from their granules (Sternlicht \& Werb 2001). This might explain why pro-MMP 9 was found to increase over time when doxorubicin was given to our rabbits. Because of its cardiotoxicity, doxorubicin is recognized to produce an intense inflammation within the myocardium, which was previously documented in this animal model of cardiomyopathy (Gava et al. 2013). A potential reason for the reduction in pro-MMP 2 over time is related to the high concentration of TIMP 4 within the cardiac tissue, contributing to the regulation of its integrity and decreasing MMP-induced capillary permeability similarly to what was formerly demonstrated in clinical conditions that damage the blood-brain barrier (Rosenberg et al. 1998). Besides the inhibition of MMPs enzyme activity by TIMPs, it must be emphasized that MMPs activity is a complex process that also comprises regulation of MMPs gene expression, which can be inhibited by TGF- $\beta$ whose pathway is known to be involved in doxorubicin-induced cardiovascular remodeling, as well as the regulation of MMPs enzyme activity by "switch" mechanism (Papazafiropoulou \& Tentolouris 2009, Sun et al. 2016).

Tissue doppler has long been accepted as a sensitive technique for the detection of subclinical myocardial impairment in children treated with anthracyclines (Kapusta et al. 2000). In this study, we documented significant changes in mitral annular diastolic velocities. The ratio between mitral $\mathrm{E}$ wave and mitral annular early diastolic velocity at the septal site, which is an index used to estimate left-ventricular filling pressures and congestion well recognized in other species (Oyama et al. 2004), increased in accordance with the deterioration of cardiac function. Interestingly, it was inversely correlated with the plasma activity of pro-MMP 2, which reduced with the progression of cardiac remodeling. Concerning mitral annular systolic velocity, an obvious trend of reduction was seen for both $S_{\text {lat }}$ and $S_{\text {sep }}$, but no correlation was attained between these two parameters and MMP activity.

Even though correlations were not found to exist between the plasma activity of pro-MMP and most echocardiographic parameters which pointed toward the compromise of cardiac structure and function, the documented changes in plasma activities of pro-MMP 2 and 9 are likely representative of the key role played by theses enzymes at the remodeling process ascribed to doxorubicin toxicity. In people with acute myocardial infarction, an increase of 39\% in the probability of ventricular remodeling was reported for each elevation of one unit in MMP 2 level (Cogni et al. 2013). This substance behaves in a similar fashion when other tissues undergo either pathological or physiological remodeling (Navarro et al. 2006, Morales et al. 2007).

It is worth mentioning, however, that the toxicity attributable to doxorubicin involves not only the heart. Hematological, gastrointestinal, cutaneous, and renal alterations are all anticipated in subjects undergoing anthracycline therapy (Speyer et al. 1988, Steinherz et al. 1991, Shakir \& Rasul 2009, Gava et al. 2013). Because MMP are found throughout the body and are involved with several biological events
(Armstrong and Jude 2002), the plasma activity of these enzymes are likely influenced by their contribution in all these tissues, and not only related to the degradation of cardiac ECM. Although our results did document changes in the plasma activity of pro-MMP 2 and 9, no relationship could be validated between these changes and the echocardiographic parameters supportive of cardiac injury.

Serum samples are known to provide artificially elevated MMP levels in comparison with plasma samples (Gerlach et al. 2007). In fact, preanalytical conditions and other methodological issues have been demonstrated to interfere with the measurement of either plasma or serum MMP 2 and 9 activities. In this study, we chose citrate as the preferred anticoagulant for blood samples because it has been shown to avoid the release of collagenases by the blood cells, yet another study mentioned that all common anticoagulants are associated with augmentation of MMP 9 and reduction of MMP 2 levels (Meisser et al. 2005). Also, because these enzymes are instable and may potentially reflect release of proteases by leukocytes during the clotting process, either serum or plasma concentrations of proteases do not necessarily reflect their tissue activity (Ferretti et al. 2006), as we observed in this investigation. Conversely, a prior study attested the important role played by these enzymes in people with advanced melanoma because serum MMP 9, in particular, was able to identify individuals with high-risk for progression (Nikkola et al. 2005).

The applicability of collagenases as biomarkers has been extensively investigated over the last years in human beings and several other species. When people with isolated systolic hypertension were compared with healthy subjects, an increased serum MMP 9 activity was found and the elevated levels were able to predict aortic stiffness (Yasmin et al. 2005). A study that included 29 patients with acute myocardial infarction showed an association between elevated serum level of pro-MMP 9 and preserved left-ventricular volumes, whereas elevated MMP 2 was found to be a prognostic marker for ventricular remodeling six months after the ischemic event (Cogni et al. 2013). Also, the increased serum levels of MMP 9 in people with chronic Chagas cardiomyopathy were demonstrated to be associated with the severity of cardiac impairment (Bautista-López et al. 2013). In this study, however, no relationship could be demonstrated between these substances measured in both myocardial and plasma samples, in spite of the myocardial activity of MMP testing lower in treated rabbits than in controls. Also, the myocardial activity was not correlated with the echocardiographic markers of cardiac dysfunction. All these findings, in conjunction, disqualify the use of these substances as surrogates for cardiac remodeling in response to doxorubicin treatment in rabbits undergoing the same experimental conditions.

Nonetheless, we do acknowledge the limitations of this investigations, which include the small number of animals recruited, the absence of a control group and a group of rabbits being given other dosages of doxorubicin to compare the role played by its well-known dose-dependent cardiotoxicity on the activity of both plasma and myocardial MMP. Also, the plasma MMP found in this investigation is not likely the sole result of cardiotoxicity, but may represent the toxicity of doxorubicin in several body tissues. Finally, we do recognize that gel-to-gel variation might exist, which could potentially interfere with the 
results, although care was taken to avoid misinterpretation by having the same operator do the zymograms and perform the densitometry to assess the gelatinolytic activity at all times.

\section{CONCLUSIONS}

In spite of the absence of the active form of MMP 2 and 9 , doxorubicin changed the activity of plasma full-length forms over time. While a reduction was documented for pro-MMP 2 , an increase was observed for pro-MMP 9 in most rabbits.

These changes were not correlated with the conventional echocardiographic parameters that are supportive of cardiac dilation and dysfunction, which preclude their use as biomarkers for myocardial remodeling.

Also, while myocardial pro-MMP 2 was significantly reduced in comparison with normal animals, it was not correlated with the echocardiogaphic data as well.

Further studies might clarify how these enzymes would behave if the animals progressed to severe congestive heart failure.

Acknowledgments.- The authors thank Conselho Nacional de Desenvolvimento Científico e Tecnológico (CNPq) for the financial support of this study.

\section{REFERENCES}

Adamcová M., Potacova A., Popelova O., Sterba M., Mazurova Y., Aupperle H. \& Gersl V. 2010. Cardiac remodeling and MMPs on the model of chronic daunorubicin-induced cardiomyopathy in rabbits. Physiol. Res. 59(5):831836. PMid:20406046.

Armstrong D.G. \& Jude E.B. 2002. The role of matrix metalloproteinases in wound healing. J. Am. Podiatr. Med. Assoc. 92(1):12-18. PMid:11796794. http://dx.doi.org/10.7547/87507315-92-1-12.

Bautista-López N.L., Morillo C.A., López-Jaramillo P., Quiroz R., Luengas C., Silva S.Y., Galipeau J., Lalu M.M. \& Schulz R. 2013. Matrix metalloproteinases 2 and 9 as diagnostic markers in the progression to Chagas cardiomyopathy. Am. Heart J. 165(4):558-566. PMid:23537973. http://dx.doi.org/10.1016/j. ahj.2013.01.001.

Cogni A.L., Farah E., Minicucci M.F., Azevedo O.S., Okoshi K., Matsubara B.B., Zanati S., Haggeman R., Paiva S.A.R. \& Zornoff L.A.M. 2013. Metaloproteinases-2 and -9 predict left ventricular remodeling after myocardial infarction. Arq. Bras. Cardiol. 100(4):315-321. PMid:23525272.

Díez J. 2010. Altered degradation of extracellular matrix in myocardial remodelling: the growing role of cathepsins and cystatins. Cardiovasc. Res. 87(4):591-592. PMid:20573730. http://dx.doi.org/10.1093/cvr/cvq208.

Ferretti G., Fabi A., Carlini P., Papaldo P., Felici A. \& Cognetti F. 2006. What is the biological significance of circulating blood levels of metalloproteinases? Clin. Cancer Res. 12(11 Pt 1):3550-3551. PMid:16740783. http://dx.doi. org/10.1158/1078-0432.CCR-06-0166.

Gava F.N., Zacché E., Ortiz E.M.G., Champion T., Bandarra M.B., Vasconcelos R.O., Barbosa J.C. \& Camacho A.A. 2013. Doxorubicin induced dilated cardiomyopathy in a rabbit model: an update. Res. Vet. Sci. 94(1):115-121. PMid:22902286. http://dx.doi.org/10.1016/j.rvsc.2012.07.027.

Gerlach R.F., Demacq C., Jung K. \& Tanus-Santos J.E. 2007. Rapid separation of serum does not avoid artificially higher matrix metalloproteinase (MMP)-9 levels in serum versus plasma. Clin. Biochem. 40(1-2):119-123. PMid:17150202. http://dx.doi.org/10.1016/j.clinbiochem.2006.10.007.

Goto T., Takase H., Toriyama T., Sugiura T., Sato K., Ueda R. \& Dohi Y. 2003. Circulating concentrations of cardiac proteins indicate the severity of congestive heart failure. Heart 89(11):1303-1307. PMid:14594884. http:// dx.doi.org/10.1136/heart.89.11.1303.
Ivanová M., Dovinová I., Okruhlicová L'., Tribulová N., Šimončíková P., Barte-ková M., Vlkovičová J. \& Barančík M. 2012. Chronic cardiotoxicity of doxorubicin involves activation of myocardial and circulating matrix metalloproteinases in rats. Acta Pharmacol. Sin. 33(4):459-469. PMid:22447222. http://dx.doi. org/10.1038/aps.2011.194.

Kapusta L., Thijssen J.M., Cuypers M.H., Peer P.G. \& Daniels 0.2000. Assessment of myocardial velocities in healthy children using tissue Doppler imaging. Ultrasound Med. Biol. 26(2):229-237. PMid:10722912. http://dx.doi. org/10.1016/S0301-5629(99)00102-7.

Kizaki K., Ito R., Okada M., Yoshioka K., Uchide T., Temma K., Mutoh K., Uechi M. \& Hara Y. 2006. Enhanced gene expression of myocardial matrix metalloproteinases 2 and 9 after acute treatment with doxorubicin in mice. Pharmacol. Res. 53(4):341-346. PMid:16455267. http://dx.doi. org/10.1016/j.phrs.2006.01.001.

Li Y.Y., Feldman A.M., Sun Y. \& McTiernan C.F. 1998. Differential expression of tissue inhibitors of metalloproteinases in the failing human heart. Circulation 98(17):1728-1734. PMid:9788826. http://dx.doi.org/10.1161/01. CIR.98.17.1728.

Ljungvall I., Rajamaki M.M., Crosara S., Olsen L.H., Kvart C., Borgarelli M., Hoglund K. \& Haggstrom J. 2011. Evaluation of plasma activity of matrix metalloproteinase- 2 and -9 in dogs with myxomatous mitral valve disease. Am. J. Vet. Res. 72(8):1022-1028. PMid:21801058. http://dx.doi. org/10.2460/ajvr.72.8.1022.

Loftus I.M. \& Thompson M.M. 2002. The role of matrix metalloproteinases in vascular disease. Vasc. Med. 7(2):117-133. PMid:12402992. http:// dx.doi.org/10.1191/1358863x02vm420ra.

Machado G.F., Melo G.D., Moraes O.C., Souza M.S., Marcondes M., Perri S.H. \& Vasconcelos R.O. 2010. Differential alterations in the activity of matrix metalloproteinases within the nervous tissue of dogs in distinct manifestations of visceral leishmaniasis. Vet. Immunol. Immunopathol. 136(3-4):340345. PMid:20430448. http://dx.doi.org/10.1016/j.vetimm.2010.03.024.

Melo G.D., Marangoni N.R., Marcondes M., Lima V.M.F. \& Machado G.F. 2011. High levels of serum matrix metalloproteinases in dogs with natural visceral leishmaniosis: a preliminary report. Vet. J.188(2):243-245. PMid:20418130. http://dx.doi.org/10.1016/j.tvjl.2010.03.017.

Meisser A., Cohen M. \& Bischof P. 2005. Concentrations of circulating gelatinases (matrix metalloproteinase-2 and -9) are dependent on the conditions of blood collection. Clin. Chem. 51(1):274-276. PMid:15613733. http:// dx.doi.org/10.1373/clinchem.2004.041707.

Morales D.S.R., Penido N.O., Silva I.D.C.G., Stávale J.N., Guilherme A. \& Fukuda Y. 2007. Matriz Metaloproteinase 2: um importante marcador genético para colesteatomas. Rev. Bras. Otorrinolaringol. 73(1):55-61. http:// dx.doi.org/10.1590/S0034-72992007000100009.

Navarro V.P., Nelson-Filho P., Silva L.A.B. \& Freitas A.C.A. 2006. Participation of matrix metalloproteinases in the pathophysiological processes of the oral cavity. Revta Odontol. Unesp 35:233-238.

Nikkola J., Vihinen P., Vuoristo M.S., Kellokumpu-Lehtinen P., Kähäri V.M. \& Pyrhönen S. 2005. High serum levels of matrix metalloproteinase-9 and matrix metalloproteinase- 1 are associated with rapid progression in patients with metastatic melanoma. Clin. Cancer Res. 11(14):5158-5166. PMid:16033831. http://dx.doi.org/10.1158/1078-0432.CCR-04-2478.

Oyama M.A., Sisson D.D., Bulmer B.J. \& Constable P.D. 2004. Echocardiographic estimation of mean left atrial pressure in a canine model of acute mitral valve insufficiency. J. Vet. Intern. Med. 18(5):667-672. PMid:15515583. http://dx.doi.org/10.1111/j.1939-1676.2004.tb02604.x.

Papazafiropoulou A. \& Tentolouris N. 2009. Matrix metalloproteinases and cardiovascular diseases. Hippokratia 13(2):76-82. PMid:19561775.

Peterson J.T., Li H., Dillon L. \& Bryant J.W. 2000. Evolution of matrix metalloproteinase and tissue inhibitor expression during heart failure progression in the infarcted rat. Cardiovasc. Res. 46(2):307-315. PMid:10773235. http://dx.doi.org/10.1016/S0008-6363(00)00029-8. 
Robert V., Besse S., Sabri A., Silvestre J.S., Assayag P., Nguyen V.T., Swynghedauw B. \& Delcayre C. 1997. Differential regulation of matrix metalloproteinases associated with aging and hypertension in the rat heart. Lab. Invest. 76(5):729-738. PMid:9166291.

Rosenberg G.A., Estrada E.Y., DencoffJ.E. \& Hsu C.Y. 1998. Matrix metalloproteinases and TIMPs are associated with blood-brain barrier opening after reperfusion in rat brain. Stroke 29(10):2189-2195. PMid:9756602. http://dx.doi. org/10.1161/01.STR.29.10.2189.

Schulz R. 2007. Intracellular targets of matrix metalloproteinase-2 in cardiac disease: rationale and therapeutic approaches. Annu. Rev. Pharmacol. Toxicol. 47(1):211-242. PMid:17129183. http://dx.doi.org/10.1146/ annurev.pharmtox.47.120505.105230.

Shakir D.K. \& Rasul K.I. 2009. Chemotherapy induced cardiomyopathy: pathogenesis, monitoring and management. J. Clin. Med. Res. 1(1):8-12. PMid:22505958.

Sousa M.G., Paulino-Junior D., Pascon J.P.E., Pereira-Neto G., Carareto R. \& Camacho A.A. 2014. Assessment of the Tei index of myocardial performance in dogs with doxorubicin-induced cardiomyopathy. Arch. Med. Vet. 46(1):6368. http://dx.doi.org/10.4067/S0301-732X2014000100009.

Speyer J.L., Green M.D., Kramer E., Rey M., Sanger J., Ward C., Dubin N., Ferrans V., Stecy P., Zeleniuch-Jacquotte A., Wernz J., Feit F., Slater W., Blum R. \& Muggia F. 1988. Protective effect of the bispiperazinedione ICRF-187 against doxorubicin-induced cardiac toxicity in women with advanced breast cancer. N. Engl. J. Med. 319(12):745-752. PMid:3137469. http:// dx.doi.org/10.1056/NEJM198809223191203.

Spinale F.G., Coker M.L., Heung L.J., Bond B.R., Gunasinghe H.R.A., Etoh T., Goldberg A.T., Zellner J.L. \& Crumbley A.J. 2000. Matrix metalloproteinase induction/activation system exists in the human left ventricular myocardium and is upregulated in heart failure. Circulation 102(16):1944-1949. PMid:11034943. http://dx.doi.org/10.1161/01.CIR.102.16.1944.

Steinherz L.J., Steinherz P.G., Tan C.T.C., Heller G. \& Murphy M.L. 1991. Cardiac toxicity 4 to 20 years after completing anthracycline therapy. JAMA 266(12):1672-1677. PMid:1886191. http://dx.doi.org/10.1001/ jama.1991.03470120074036.
Sternlicht M.D. \& Werb Z. 2001. How matrix metalloproteinases regulatecell behavior. Annu. Rev. Cell Dev. Biol. 17(1):463-516. PMid:11687497. http:// dx.doi.org/10.1146/annurev.cellbio.17.1.463.

Sun Z., Schriewer J., Tang M., Marlin J., Taylor F., Shohet R.V. \& Konorev E.A. 2016. The TGF- $\beta$ pathway mediates doxorubicin effects on cardiac endothelial cells. J. Mol. Cell. Cardiol PMid:26686989.

Stypmann J., Engelen M.A., Breithardt A.K., Milberg P., Rothenburger M. Breithardt O.A., Breithardt G., Eckardt L. \& Cordula P.N. 2007. Doppler echocardiography and tissue Doppler imaging in the healthy rabbit: differences of cardiac function during awake and anaesthetized examination. Int. J. Cardiol. 115(2):164-170. PMid:16806537. http://dx.doi.org/10.1016/j. ijcard.2006.03.006.

Thomas C.V., Coker M.L., Zellner J.L., Handy J.R., Crumbley 3rd R.D.A.J. \& Spinale F.G. 1998. Increased matrix metalloproteinase activity and selective upregulation in myocardium from patients with end-stage dilated cardiomyopathy. Circulation 97(17):1708-1715. PMid:9591765. http:// dx.doi.org/10.1161/01.CIR.97.17.1708.

Van den Steen P.E., Van Aelst I., Starckx S., Maskos K., Opdenakker G. \& Pagenstecher A. 2006. Matrix metalloproteinases, tissue inhibitors of MMPs and TACE in experimental cerebral malaria. Lab. Invest. 86(9):873-888. PMid:16865090. http://dx.doi.org/10.1038/labinvest.3700454.

Visse R. \& Nagase H. 2003. Matrix metalloproteinases and tissue inhibitors of metalloproteinases: structure. Circ. Res. 92(8):827-839. PMid:12730128. http://dx.doi.org/10.1161/01.RES.0000070112.80711.3D.

Yasmin, McEniery C.M., Wallace S., Dakham Z., Pulsalkar P., Maki-Petaja K., Ashby M.J., Cockcroft J.R. \& Wilkinson I.B. 2005. Matrix metalloproteinase-9 (MMP-9), MMP-2, and serum elastase activity are associated with systolic hypertension and arterial stiffness. Arterioscler. Thromb. Vasc. Biol. 25(2):372-378. PMid:15556929. http://dx.doi.org/10.1161/01. ATV.0000151373.33830.41

Zhang W., Zhong M., Yang G.R., Li J.P., Guo C., Wang Z. \& Zhang Y. 2008. Matrix metalloproteinase-9/tissue inhibitors of metalloproteinase-1 expression and atrial structure remodeling in a dog model of atrial fibrillation: inhibition with angiotensin-converting enzyme. Cardiovasc. Pathol. 17(6):399-409. PMid:18706834. http://dx.doi.org/10.1016/j.carpath.2008.02.008. 